\title{
The Relationship between the Capital and Ownership Structures of companies listed on the Bucharest Stock Exchange
}

\author{
Raluca-Georgiana MOSCU \\ Ph.D. Student, Bucharest University of Economic Studies, Bucharest, Romania \\ E-mail: moscu.raluca@yahoo.com
}

DOI: $\quad 10.6007 /$ IJARBSS/v4-i2/628 URL: http://dx.doi.org/10.6007/IJARBSS/v4-i2/628

\begin{abstract}
This paper examines the relationship between several cases of corporate governance and capital structure of companies listed on the stock market in Romania. The study covers the period 2010-2012 for 52 listed companies, non-financial companies. Concrete cases of corporate governance used are the size of the Board of Directors, the composition of Board of Directors, CEO's duality - Chairman of the Board of Directors, the shareholder's structure and typology. Recent work on corporate finance has two important aspects of corporate governance: agent conflicts and separation of control ownership.

Key words: Corporate performance, capital structure, ownership structure, duality, institutional investors

\section{Introduction}

Agency theory argues that there is a conflict of interest between managers and shareholders. Separation of control ownership leads to the conclusion that managers pursue their own interests and do not want to maximize the value of shareholders' wealth. Thus we considered important for this research the impact of structure of concentrated type of shareholder, of the shareholder typology regarding the decisions related to the degree of capital structure. Impact of shareholder typology was examined using the presence of shareholder of managerial type and of institutional type. The results show that the presence of non -executive members in the Board of Directors is significantly negatively correlated with degree of capital structure. The lever of listed companies is not significantly influenced by the duality of CEO/President and by the size of the Board of Directors. Control variable - the company's performance has a significant effect on the degree of capital structure.

This paper was structured as follows: Section II provides an overview of the existing literature on the subject. Section III explains the database, variables and methodology used for the empirical research, while Section IV presents the results of the study.
\end{abstract}




\section{Literature review}

The literature presents the empirical results, based on the most side on the impact of corporate governance on firm's performances or it analyses the influence of the shareholders structure on the firm's value (Claessens, 2002). However the relationship between the corporate governance and capital structureis not exploited sufficiently by the researchers. Only few authors Berger (1997), Wen (2002) and Abor (2007) analyses in their own research the influence of different cases of corporate governance on capital structure of firms from developed and emergent markets.

\section{Institutional investors - shareholders}

Numerous groups have an influence on corporate governance. Of these, institutional investors play an important role. Institutional investors are another mechanism of control on the company's management; it can influence the decisions of the firm's management. Of course, in literature the presence of institutional investors is a mechanism which can solve the problems of agent to protect the rights of small shareholders (Shleifer and Vishny, 1997).

In view of the existence of institutional investors as shareholders in the company, on the degree of capital structure, the literature asserts two contrary hypotheses: hypothesis of „incentive" and the"expropriation" one. First, the assumption of "incentive" maintains a positive result of the relationship between the presence of institutional investors as shareholders and the degree of capital structure. This hypothesis argues that agent problems occur predominantly between shareholders and managers, due to the separation of ownership from control. Therefore, the concentration of ownership in the hands of a few large shareholders, institutional investors could reduce the agent costs between shareholders and managers by achieving a successful monitoring of the activity of managers (Jensen and Meckling, 1976). According to this hypothesis, institutional investors manage to achieve an active monitoring because investing large funds in the shares of a company; they are encouraged to effectively monitor managers to protect their investment (Friend and Lang, 1988). So these institutional investors want the company to turn to debt. The money thus obtained is used to invest in profitable projects.

In contrast, expropriation hypothesis suggests that when large shareholders effectively control the company, agent problems occur mainly between large shareholders and minority shareholders. Thus institutional shareholders will follow their own interests, private benefits, leading to expropriation of minority shareholders (Shleifer and Vishny, 1997, La Porta et al., 1998). These private benefits obtained from control often occur in countries where minority investors' protection is low (Nenova, 2000). Therefore, according to this second hypothesis large shareholders may prefer their funds for financing to obtain private benefits and no external financing, so profit is not distributed as dividends to minority shareholders. Moreover, large shareholders, usually oppose to the risks assumption, so they want to avoid making highrisk investments, which in addition lead to a call to capital structure.

\section{Managers - shareholders}

When the percentage of management is low, managers ' interests are aligned with the interests of the other shareholders, leading to an increase in debt. The higher the percentage of manager - shareholder increases, the more it will use capital structure as a positive signal in the 
market, the final effect an increase in the stock exchange and respectively of the shares owned by the manager. In this case there is a positive relationship between the presence of the managers' shareholders and the company's degree of capital structure. Short, Keasey and Duxbury (2002) analyzes the influence of ownership structure on corporate capital structure in the UK. Kim and Sorenson (1986), Agrawal and Mandelker (1987) identify positive links between capital structureand variable manager - shareholder. Brailsford (2002) using a sample of 49 companies from Australia also notes that there is a positive relationship between the two variables, for a low percentage of shares owned by managers and a negative relationship for percentages above 25\%. When managers own significant percentages in the company's capital there are few constraints on the behavior of managers, leading to personal decisions, protecting their own interests and a low level of debt.

Friend, Irwin and Lang (1988) examine how management wanting to maximize their own interests, influences capital structure of companies. The authors found a negative relationship between debt and the existence of managers-shareholders. Managers' shareholders will prefer a low level of capital structure, for the remaining amounts available to them in the form of available cash flows not to be reduced with the amount of interest to be paid. Also the call to debt leads to more carefully control on the activities of managers from creditors. Creditors do not accept unprofitable investment projects, or risky projects. Jensen and Meckling (1976) note that managers shareholders have a natural tendency to maximize the interests of shareholders, but considering that a high levels of debt can lead to financial problems, managers will use a lower level of debt, as the risk of bankruptcy is associated with job loss. Once we talk of bankruptcy we question the management skills of those who administer the company.

\section{Ownership structure}

While a large number of studies have shown that ownership structure is an important tool to improve firm's performance (Jensen and Meckling 1976, Shleifer and Vishny, 1986, Demsetz and Lehn, 1985; McConnell and Servaes, 1995), relations between ownership structure and capital structureare not sufficiently investigated. The literature shows few results, rare, but mixed. Grossman and Hart (1986) and Anderson (2003) confirm that firms with concentrated ownership structure have a higher level of debt than firms with dispersed ownership, but Nam et al. (2003) has identified an inverse relationship.

Shleifer and Vishny (1986) argued that large holdings of investors can reduce the opportunism of managers. Large shareholders with significant amounts invested in the company monitors efficiently the management. Thus managers can not reduce capital structure to maximize their own interests, but must take into account that they are monitored by shareholders who want a certain level of profitability or they may claim dividends. In this situation, firms with high ownership concentration are likely to have higher debt to finance profitable investment projects.

Jensen and Meckling (1976) argue that any agency costs play an important role in the financing decision because of conflicts of interest between shareholders and creditors or between shareholders and managers. If the level of debt is high, and the company is facing financial difficulties if there are two projects one of them being more risky and the other one less risky, shareholders can force management to choose risky projects that may lead to a 
higher gain. If the project is successful, shareholders will gain after paying the debt. If the project fails, the loss is largely borne by the creditors.

Usually a concentrated ownership company prefer indebtness in exchange for a share issue, which leads to a reduction of power held control, and thus of the personal benefits provided by the position of control. As the shareholders that take decisions in the company are fewer, all the more so the creditors consider it is easier to negotiate contractual terms. Also a firm that has a concentrated ownership tends to reinvest profit to increase the company and doesn't want a dividend distribution rather modest, so besides the external funding it is preferred the one from own sources too.

\section{The Size of the Board of Directors}

Board of Directors plays a vital role in strategic decisions on financing the company - from its own sources or external sources. Pfeffer and Salancick (1978) identified a significant relationship between leverage and size of the Board. Evidence about the direction of the relationship between the size of the Board of Directors and borrowing structure are varied. The cost of debt is generally lower for a larger Board because lenders believe these companies are monitored more effectively, and hold a diversified portfolio of experts (Anderson, 2004). Berger (1997) notes that firms with a larger Board of Directors generally have a low level of capital structure. He argues that a larger size of the Board of Directors puts pressure on managers to a lower level of debt and better performance of the company. Abor and Biekpe (2007) examine the relationship between corporate governance and debt structure decisions on small and medium enterprises in Ghana, using multivariate regression analysis. The results provide evidence of a possible negative relationship between the size of the Board and capital structure.

\section{The existence of non-executive members in the Board of Directors}

Non-executive members are the cornerstone of modern corporate governance. The relationship between the presence of non-executive members and capital structure has been investigated by several authors, but the results of these are different. Pfeffer and Salancick (1978) points out that non-executive member play a vital role in increasing the capacity of companies to get recognition from external partners. Thus, we can say that the presence of these members reduces uncertainty and leads to an increase in the company's ability to raise external funds. The authors observed that a higher number of non-executive members lead to higher levels of capital structure. Jensen (1986) and Berger (1997) found that a high level of capital structure occurs in companies with a large number of non-executive members. Abor and Biekpe (2007) reached the same result: a positive relationship between the two variables.

Wen (2002) provides evidence of the existence of a negative relationship between debt level and the presence of non-executive members. One possible reason is that they monitor managers more effectively. Thus the latter do not prefer high levels of debt, not to diminish the profitability of the company.

\section{Duality of the CEO-Chairman of the Board of Directors}

Another important feature of corporate governance is the duality of CEO - Chairman of the Board of Directors. This indicates that the general manager of the company is also the 
Chairman of the Board. This has a direct impact on corporate capital structure. Fama and Jensen (1983) argue that the two roles should be separated. Thus the same person - the CEO makes decisions regarding the company's debt and he, as the Chairman, controlles how resources obtained by loan are used. Thus it is preferred a separation of duties. Heng et al, (2012) in their study they examined the relationship between the characteristics of the Board of Directors and the degree of capital structure. In this study, 75 companies listed on the Kuala Lumpur Stock Exchange during the years 2005-2008 were selected in the sample. The results showed that the size and independence of the Board of Directors have an important role in determining capital structureof companies. The author hasn't observed a negative relationship between CEO's duality and the degree of capital structure. Gill et al., (2012) has tested the relationship between corporate governance and debt for the 600 companies in India. The results indicate that there is a significant and positive relationship between the variables showing the duality of CEO - Chairman of the Board and the companies' lever. Abor and Biekpe (2007) present evidence of a positive relationship between capital structure and CEO's Chairman's duality. Hovey (2010) carried out for companies in China in 1999-2005 a similar analysis and found a significant and negative relationship.

\section{The size of the company}

Frank and Goyal (2007) starting from the pecking order theory, believe that large firms have a lower degree of capital structure. Because larger firms are more diversified and they have a more effective management, these companies face a lower default risk (Friend and Lang, 1988). A company is more likely to get a loan as it has a larger size, because the creditors know more information about the activity of the company, its history, the easier it will get a loan. Jensen (1986) and Easterbrook (1986) support the idea that between the company's size and the probability of bankruptcy there is a negative correlation, so therefore between firm's size and debt there is a positive correlation.

\section{The company's profitability}

Wippern (1966) has investigated the relationship between capital structure and firm's values. The study used the ratio debt/equity as an indicator of debt and earnings per share as a performance indicator. The results showed that debt has a positive effect on firm's value and this result confirms that shareholders' wealth can be enhanced by using external funding. In this way, Holz (2002) identified that capital structure is positively influenced by the company's performance. The result demonstrates the company's managers desire to fund projects by taking loans; the money thus obtained being used optimally to maximize performance. According to this result, if the banks will want to lend money, they will study the feasibility of the projects they would like to fund them, before offering the loan. Dessi and Robertson (2003) observed that capital structure is positively correlated with performance: companies try to use loans to utilize the growth opportunities and to invest the borrowed money in profitable projects, so this will increase the efficiency of the company. Margrates and Psillaki (2010) also demonstrated that capital structure is positively and significantly correlated with the firm's performance. 


\section{Data base and research methodology}

In this study we had as purpose the identification of sources of funding of companies listed on the Bucharest Stock Exchange and the impact of ownership structures capital structure. We chose as a sample of 53 companies listed on the Bucharest Stock Exchange and financial data were selected for 2010-2012. Initially we selected 61 companies but we removed from the sample banks and investment companies, because for these companies debt is influenced by several exogenous factors. Secondly we excluded companies that we do not have sufficient financial data prepared for this study. So I removed of the number of listed companies in the year 2012 those after 2010 listed companies also, companies for which financial statements have not ben found specific to the period 2010 to 2012 or for which I had incomplete information. 
Table 1. Variables definition

\begin{tabular}{|c|c|}
\hline Variables & Description \\
\hline DATTOT/CPR & Capital structure expressed as a ratio between total debt of company and equity \\
\hline DATTOT/AE & $\begin{array}{l}\text { Capital structure expressed as a ratio between total debt of company and } \\
\text { economic assets }\end{array}$ \\
\hline DATTOT/AT & $\begin{array}{l}\text { Capital structure expressed as a ratio between total debt of company and total } \\
\text { assets }\end{array}$ \\
\hline DATTOT/CPB & $\begin{array}{l}\text { Capital structure expressed as a ratio between total debt and market } \\
\text { capitalization }\end{array}$ \\
\hline DATFIN/CPR & $\begin{array}{l}\text { Capital structure expressed as a ratio between financial debt of company and } \\
\text { equity }\end{array}$ \\
\hline INSTIT & $\begin{array}{l}\text { The presence of institutional investors (percentage they held of the company's } \\
\text { shares) }\end{array}$ \\
\hline MAN & $\begin{array}{l}\text { The presence of managers-shareholders (percentage they held of the company's } \\
\text { shares) }\end{array}$ \\
\hline OWN & $\begin{array}{l}\text { Ownership structure (Dummy variable: } 1 \text { - majority shareholder, } 0 \text { - minority } \\
\text { shareholder) }\end{array}$ \\
\hline BORD SIZE & $\begin{array}{l}\text { The size of the Board of Directors (number of members of the Board of } \\
\text { Directors) }\end{array}$ \\
\hline $\begin{array}{l}\text { NON- } \\
\text { EXECUTIVE }\end{array}$ & $\begin{array}{l}\text { The ratio between executive and non-executive members of the Board of } \\
\text { Directors (Dummy variables: The value of dummy variable is } 1 \text {, if the ratio non- } \\
\text { executive members of the total Board of Directors is higher than the percentage } \\
\text { of executives; if not } 0 ; \text {; }\end{array}$ \\
\hline DUALITY & $\begin{array}{l}\text { The Board of Directors CEO's-Chairman's Duality (Dummy variable: } 1-\text { CEO and } \\
\text { the Chairman are the same person, } 0 \text { - there is a separation of the two } \\
\text { positions) }\end{array}$ \\
\hline SIZE & The sizee of the company (Natural logarithm of market capitalization) \\
\hline$R O A$ & Return on assets (EBIT/Economic assets) \\
\hline$R O E$ & Return on equity (Net Income/Equity) \\
\hline$R C A$ & Operating Margin (Net Income/Sales Turnover) \\
\hline
\end{tabular}




\begin{tabular}{|l|l|}
\hline$E P S$ & Earnings per share (Income after taxes/Number of Shares) \\
\hline$M B R$ & Market to Book Ratio (Market capitalization in relation to Equity) \\
\hline
\end{tabular}

\section{Empirical results}

So to test the validity of the assumptions stated above, for the practice of listed companies it was compiled a sample of 53 companies listed on the Bucharest Stock Exchange, Class I and II. Necessary financial information (balance sheet and profit and loss account) were collected from several sources: the BSE website, the Investment Consulting Company KTD Invest SA website and the Financial Investment Services Company Intercapital Invest SA website. In the regression model the dependent variable is the capital structure expressed as Total Debt/Equity, Total Debt/Total Assets, Total Debt/Economic Assets, Total Debt/Market capitalization, Financial Debt/Equity. In the regression model below we used as independent variables a vector of regressors $X_{k}$, which supposedly can influence the result $Y$. Specifically, we'll assume that the model takes the form:

$$
Y=\alpha+B_{1} \cdot X_{1}+B_{2} \cdot X_{2}+\cdots+B_{k} \cdot X_{k}+\varepsilon
$$

Where, $k=1,2, \ldots 53$ (number of companies listed in Bucharest Stock Exchange), $Y$ dependent variable which measures capital structure, $X_{k}$ - independent variables described in table no. 1

Table 2. Descriptive Statistics

\begin{tabular}{|c|c|c|c|c|c|c|c|c|c|c|c|c|c|}
\hline & - & 一 & 一 & $\stackrel{\oplus}{0}$ & $>\quad \stackrel{\circ}{\stackrel{0}{U}}$ & $\stackrel{\models}{\underline{E}}$ & $\frac{z}{z}$ & 3 & $\frac{\vec{b}}{\frac{m}{n}} \frac{w}{n}$ & 崖 & $\frac{E}{5}>$ & $\frac{山}{N}$ & 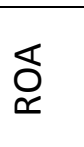 \\
\hline $\begin{array}{l}\text { Mea } \\
n\end{array}$ & 1.3 & 0.4 & 0.5 & 0.04 & 0.8 & 0.3 & $\begin{array}{c}0.0 \\
8\end{array}$ & 0.8 & 5 & 0.9 & 0.3 & $\begin{array}{c}17 . \\
5\end{array}$ & $\begin{array}{c}0.0 \\
3\end{array}$ \\
\hline $\begin{array}{l}\text { Med } \\
\text { ian }\end{array}$ & 0.3 & 0.3 & 0.3 & 0.0 & 0.03 & 0.3 & 0.0 & 1.0 & 5 & 1.0 & 0.0 & $\begin{array}{c}17 . \\
3\end{array}$ & $\begin{array}{c}0.0 \\
8\end{array}$ \\
\hline Max & 157.7 & 6.6 & 43.4 & 5.8 & 123.4 & 0.9 & 0.7 & 1.0 & 11 & 1.0 & 1.0 & $\begin{array}{c}23 . \\
9\end{array}$ & $\begin{array}{c}1.7 \\
6\end{array}$ \\
\hline Min & -49.3 & -3.0 & -49.3 & 0.0 & -27.0 & 0.0 & 0.0 & 0.0 & 3 & 0.0 & 0.0 & $\begin{array}{c}14 . \\
3\end{array}$ & $\begin{array}{c}- \\
8.6\end{array}$ \\
\hline
\end{tabular}

From information provided by descriptive statistics it is observed that the average weight of shares owned by institutional investors in total shares listed on capital market in Romania is of $30 \%$, the peak reached in a company being over $90 \%$. The management of companies listed on the Bucharest Stock Exchange has only eight percentages (8\%) of the total shares listed for 
the 53 companies listed. The ownership structure is a concentrated one, given that over $80 \%$ of listed companies have one or two shareholders aggregate holding more than $50 \%$ of the shares of a company. On the capital market in Romania it is observed the preference for low Board of Directors consisted of five members on average. Another conclusion drawn from descriptive statistics is that over $90 \%$ of listed companies have a higher percentage of non -executive members in the Board of Directors than the executive members. Regarding the degree of financial debts it is observed that on average, companies that choose short-term debt and financial debts reach a debt of over $40 \%$. There is a preference for financial debts; their share in total equity is over $80 \%$. Instead the ponderosity of total debts in total equity reaches on average to $130 \%$.

It is noted that when the number of non - executives members is higher capital structure is reduced, the sign of the regression coefficient is negative and equal to -5.591 , model no.1 in Table 3. We consider that these members serve to better monitor the activity of manager, to take the necessary measures to sanction him when he is acting for its own interests and he doesn't protect the interests of minority shareholders.

Negative relationship between the two variables - debts and non-executive members outnumber the executive ones - is confirmed in the model no. 2, 3 and no. 5 also, where we uses as size of capital structure the ratio between total debt of the company, on the one hand and economic assets, total assets and respectively market capitalization, on the other hand. These negative relationships are confirmed by Wen (2002) also. He also tests the connection and notes the existence of a negative relationship between the capital structure and the presence of non -executive members. One possible reason is that they monitor managers more effectively. The presence of non -executive members is a means of reducing agent problems and they are designed to reduce conflicts in the companies. So these members can supervise others not to opt for a level of capital structure used for their own interests. Closely monitored, managers will maintain debt at the lowest possible level, a level considered optimal for the activity of the company. Other empirical confirmations of the positive relationship are those of the authors Ezzamel (1993) - in an analysis of companies in the UK, Hossain et al. (2001) for the practice of companies in New Zealand.

Table 3. Testing the impact of ownership structure on capital structure of companies listed in the Bucharest Stock Exchange

\begin{tabular}{|c|c|c|c|c|c|c|c|c|c|c|c|c|}
\hline $\begin{array}{l}\text { Dependen } \\
t \text { variables }\end{array}$ & \multicolumn{2}{|c|}{$\begin{array}{c}\text { DATTOT/C } \\
\text { PR }\end{array}$} & \multicolumn{2}{|c|}{$\begin{array}{c}\text { DATTOT/A } \\
\text { E }\end{array}$} & \multicolumn{2}{|c|}{$\begin{array}{c}\text { DATTOT/A } \\
T\end{array}$} & \multicolumn{2}{|c|}{$\begin{array}{c}\text { DATTOT/A } \\
\mathbf{T}\end{array}$} & \multicolumn{2}{|c|}{$\begin{array}{c}\text { DATTOT_CP } \\
\text { B }\end{array}$} & \multicolumn{2}{|c|}{$\begin{array}{c}\text { DATFIN_CP } \\
R\end{array}$} \\
\hline & \multicolumn{2}{|c|}{ Model 1} & \multicolumn{2}{|c|}{ Model 2} & \multicolumn{2}{|c|}{ Model 3} & \multicolumn{2}{|c|}{ Model 4} & \multicolumn{2}{|c|}{ Model 5} & \multicolumn{2}{|c|}{ Model 6} \\
\hline $\begin{array}{c}\text { Independe } \\
\text { nt } \\
\text { variables }\end{array}$ & $\begin{array}{c}\text { Coef } \\
\text { f. }\end{array}$ & $\begin{array}{c}\text { Pro } \\
\text { b. }\end{array}$ & $\begin{array}{c}\text { Coef } \\
\text { f. }\end{array}$ & $\begin{array}{c}\text { Pro } \\
\text { b. }\end{array}$ & $\begin{array}{c}\text { Coef } \\
\text { f. }\end{array}$ & $\begin{array}{l}\text { Pro } \\
\text { b. }\end{array}$ & $\begin{array}{c}\text { Coef } \\
\text { f. }\end{array}$ & Prob & $\begin{array}{c}\text { Coeff } \\
.\end{array}$ & $\begin{array}{c}\text { Pro } \\
\text { b. }\end{array}$ & $\begin{array}{c}\text { Coef } \\
\mathrm{f} .\end{array}$ & $\begin{array}{c}\text { Pro } \\
\text { b. }\end{array}$ \\
\hline $\begin{array}{c}\text { Institution } \\
\text { al }\end{array}$ & & & & & & & $\begin{array}{c}0.27 \\
9\end{array}$ & $\begin{array}{c}0.06 \\
6\end{array}$ & & & $\begin{array}{c}- \\
2.05\end{array}$ & 0.08 \\
\hline
\end{tabular}




\begin{tabular}{|c|c|c|c|c|c|c|c|c|c|c|c|c|}
\hline $\begin{array}{l}\text { Dependen } \\
t \text { variables }\end{array}$ & \multicolumn{2}{|c|}{$\begin{array}{c}\text { DATTOT/C } \\
\text { PR }\end{array}$} & \multicolumn{2}{|c|}{$\begin{array}{c}\text { DATTOT/A } \\
\text { E }\end{array}$} & \multicolumn{2}{|c|}{$\begin{array}{c}\text { DATTOT/A } \\
T\end{array}$} & \multicolumn{2}{|c|}{$\begin{array}{c}\text { DATTOT/A } \\
T\end{array}$} & \multicolumn{2}{|c|}{$\begin{array}{c}\text { DATTOT_CP } \\
\text { B }\end{array}$} & \multicolumn{2}{|c|}{$\underset{\mathbf{R}}{\text { DATFIN_CP }}$} \\
\hline & \multicolumn{2}{|c|}{ Model 1} & \multicolumn{2}{|c|}{ Model 2} & \multicolumn{2}{|c|}{ Model 3} & \multicolumn{2}{|c|}{ Model 4} & \multicolumn{2}{|c|}{ Model 5} & \multicolumn{2}{|c|}{ Model 6} \\
\hline $\begin{array}{c}\text { Independe } \\
\text { nt } \\
\text { variables }\end{array}$ & $\begin{array}{c}\text { Coef } \\
\text { f. }\end{array}$ & $\begin{array}{l}\text { Pro } \\
\text { b. }\end{array}$ & $\begin{array}{c}\text { Coef } \\
\mathrm{f} .\end{array}$ & $\begin{array}{l}\text { Pro } \\
\text { b. }\end{array}$ & $\begin{array}{c}\text { Coef } \\
f .\end{array}$ & $\begin{array}{l}\text { Pro } \\
\text { b. }\end{array}$ & $\begin{array}{c}\text { Coef } \\
\mathrm{f} .\end{array}$ & $\begin{array}{c}\text { Prob } \\
.\end{array}$ & $\begin{array}{c}\text { Coeff } \\
.\end{array}$ & $\begin{array}{l}\text { Pro } \\
\text { b. }\end{array}$ & $\begin{array}{c}\text { Coef } \\
\text { f. }\end{array}$ & $\begin{array}{l}\text { Pro } \\
\text { b. }\end{array}$ \\
\hline \multicolumn{13}{|l|}{$\begin{array}{l}\text { Managem } \\
\text { ent }\end{array}$} \\
\hline \multicolumn{13}{|l|}{ Ownership } \\
\hline \multicolumn{13}{|l|}{$\begin{array}{c}\text { The size of } \\
\text { Bord of } \\
\text { Directors }\end{array}$} \\
\hline $\begin{array}{c}\text { Non- } \\
\text { executives }\end{array}$ & $\begin{array}{c}- \\
5.59\end{array}$ & 0.03 & 1.37 & 0.11 & $\begin{array}{c}- \\
0.19 \\
4\end{array}$ & 0.13 & & & $\begin{array}{c}- \\
0.175 \\
2\end{array}$ & 0.05 & & \\
\hline Duality & & & & & $\begin{array}{c}- \\
0.16 \\
4\end{array}$ & 0.13 & & & & & & \\
\hline \multicolumn{13}{|l|}{$\begin{array}{c}\text { Size of } \\
\text { Company }\end{array}$} \\
\hline $\begin{array}{c}\text { Profitabilit } \\
y\end{array}$ & 4.80 & 0.00 & 4.66 & 0.00 & $\begin{array}{c}0.35 \\
7\end{array}$ & 0.02 & $\begin{array}{c}0.28 \\
3\end{array}$ & 0.07 & & & $\begin{array}{c}- \\
7.11\end{array}$ & 0.00 \\
\hline $\mathrm{R}^{2}$ & \multicolumn{2}{|c|}{$8.99 \%$} & \multicolumn{2}{|c|}{$39.93 \%$} & \multicolumn{2}{|c|}{$5.18 \%$} & \multicolumn{2}{|c|}{$4.74 \%$} & \multicolumn{2}{|c|}{$2.37 \%$} & \multicolumn{2}{|c|}{$75.19 \%$} \\
\hline $\begin{array}{c}\text { Adjusted } \\
\mathrm{R}^{2}\end{array}$ & \multicolumn{2}{|c|}{$7.82 \%$} & \multicolumn{2}{|c|}{$39.15 \%$} & \multicolumn{2}{|c|}{$3.33 \%$} & \multicolumn{2}{|c|}{$3.51 \%$} & \multicolumn{2}{|c|}{$1.74 \%$} & \multicolumn{2}{|c|}{$74.87 \%$} \\
\hline DW-stat & \multicolumn{2}{|c|}{2.055} & \multicolumn{2}{|c|}{2.034} & \multicolumn{2}{|c|}{2.086} & \multicolumn{2}{|c|}{2.028} & \multicolumn{2}{|c|}{1.968} & \multicolumn{2}{|c|}{2.049} \\
\hline $\begin{array}{l}\text { Prob (F- } \\
\text { statistic) }\end{array}$ & \multicolumn{2}{|c|}{0.0006} & \multicolumn{2}{|c|}{0.000} & 0.0 & & & & 0.0 & & & \\
\hline
\end{tabular}

For model no. 4, respectively no. 6 of Table 3 we've found significant relationships between the presence of institutional investors and the degree of capital structure. For model no. 4 of the table no. 4 it is seen that the existence of institutional investors has a positive impact on capital structure expressed as Total Debt/Total Assets, the regression coefficient is equal to 0.2799 . So the institutional investors positively influence the capital structure 
measured as ratio between total debt and total assets. For the model no. 6 of the table no. 3 it is observed that the existence of institutional investors negative influence debt expressed as financial debts in relation to equity of listed companies. Both relationships have theoretical explanations drawn from the literature.

The coefficient regression model no. 6 of the table 3 is negative and equal to -2.0594 , indicating that the presence of institutional investors has a negative impact on the financial degree of capital structure (financial debt/equity). So on the one hand the presence of institutional investors and debt can be interchangeable (Jensen, 1986). Company's managers can obtain financing from creditors, but also institutional investors can bring significant funds in the company. The very presence of institutional investors in the company is a means of signaling to investors in the market (Ross, 1977). Thus, the company doesn't need to call on debt to signal future performances. The presence of institutional investors offers to investors in the market a positive signal. Since institutional investors better understand the value of a company, the proportion of shares held by institutional investors provide a signal about the value of the firm for minority investors, so they become more interested in shares of that company. Also relationships in listed companies with institutional investors are better defined, the latter define with company's management the policy action, how to monitor the activity of manager, the organization method of meetings with company's management etc. So a negative relationship can be inferred from the very role of institutional investors - to monitor the funds provided to managers, to monitor their activity that leads to the level of profitability desired by investors. Institutional investors are also better informed than are individual investors. Institutional investors allocate resources for better monitoring, information, and also sometimes they benefit from privileged corporate information to which individual investors do not have access (Michaely and Shaw, 1994). According to research conducted by Grossman and Hart (1980), Shleifer and Vishny (1986) management should be monitored and this monitoring should be performed by large shareholders.

On the other hand, the presence of institutional investors and the capital structure could be complementary. Sometimes to enhance the protection of shareholders, institutional investors implement mechanisms such debt by which the actions of managers are limited, supervised, everything to get a good alignment of the objectives of managers and shareholders (La Porta et al, 2000). Managers have information on future profitability of the company, or investment opportunities, which are not known to investors outside the company. Generally, debt can attenuate this problem regarding the information asymmetry, the gap between stakeholders inside and outside the company. This suggests that firms with higher levels of information asymmetry will have a higher capital structure. This positive relationship is presented in the model no. 4 of the table 4 where the sign of the regression coefficient is positive and equal to 0.279 .

Profitability, expressed as return on assets (ROA), negatively influence the capital structure expressed as ratio of financial debts/equity in the model no. 6 of the table no. 4. This conclusion supports the pecking order theory. Pecking order theory of equity argues that companies prefer reinvestment of profit to be their main source of investments financing and second place opting for debt (Myers and Majluf, 1984). According to this theory, profitable firms rely mainly on the profits carried forward to finance the investments. It is therefore expected a negative relationship between profitability and debt. Studies of authors Abor (2005) 
for companies listed in Ghana, Krishnan and Moyer (1997) - for Asian corporations, King and Santor (2008) for companies in Canada confirm the negative relation between the two variables.

Profitability, expressed as return on assets (ROA), positively affects capital structure expressed as Total Debt/Total Assets, Debt/Economic Assets and Debt/Equity, regression coefficients are positive and equal to $0.3573,4.669$ and 4.8009 for models no. 3, no. 2 and model no. 1 from Table 4. Thus is confirmed signal theory. On the other hand, the trade- off theory (Jensen \& Meckling, 1976) states that profitable firm prefers debts to take advantage of tax, which leads to a positive relationship between the capital structure and profitability. A firm obtains sufficient income by debt to cover its expenses, including the ones with interest on loans and can benefit from the tax savings associated with debt. Agency theory (Jensen \& Meckling, 1976, Jensen, 1986; Easterbrook, 1984) also states that by debt managers are monitored and are forced to spend excess cash flow for the payment of interest and rates associated with contracted loans.

According to Champion (1999), debt is a way to improve firm performance. Abor (2007) found that there is a positive relationship between short-term debt and return on assets in South Africa, as short-term debt is cheaper than long term debt. Lara and Mesquita (2003) have also found similar results in their study on Brazilian companies. Therefore, this study also leads to the hypothesis that there is a positive relationship between debt and return on asset, confirming the results of the studies cited above. Dessi and Robertson (2003), Margrates and Psillaki (2010) confirmed the positive relationship between debt and profitability expressed as return on asset.

In all the three years analyzed 2010-2012 we observed that capital structure is precise of a rate starting from $2.73 \%$ for model no. 5 to $75.19 \%$ for model no.6.

\section{Conclusions}

This research has as purpose the examination of relationship established between the capital structure and some cases on ownership structures - the presence of institutional investors, of managers shareholders, ownership structure, the size of the Board of Directors, the existence of a higher percentage of non -executive members, the duality General Manager Chairman of the Board of Directors, the size and profitability of the company, for a sample of 53 companies listed on the Bucharest Stock Exchange, in 2010-2012.

From the results of the empirical analysis it is observed that the profitability, expressed as return on assets (ROA), negatively influence the capital structure expressed as ratio of financial debts/equity. This conclusion supports the pecking order theory, according to which profitable companies are less indebted, because they use internal resources to finance investment projects and not the long-term debt. Also the results of the empirical analysis show that profitability, expressed as return on assets (ROA), positively affects capital structure expressed as Total Debt/Total Assets, Debt/Economic Assets or Debt/Equity. Managers consider debt a positive signal to investors in the market. Debt provides "confidence" to investors that they have made the best choice. As capital structure is higher, the more the company is more profitable and vice versa, in terms of high profitability the company may draw on loans so that from own and borrowed sources to be able to fund profitable investment projects. 
Changes regarding capital structure may transmit information on a company's profitability and risk. An underperforming firm may have a low market value, but managers will be able to demonstrate that, in fact, their company is undervalued when they turn to debt and they will be able to support debt service. Knowing that in case of wrong signals managers will incur penalties; investors will have strong reasons to believe that the situation of the company is much better.

From the results of the empirical analysis it is observed that the variable showing that the number that the number of non -executive members within the Board of Directors is higher than that of the executives ones, significantly influence the degree of capital structure, negatively. This negative relationship can be explained by the fact that the role of non executive members is to monitor management for the latter to take the best decisions to increase firm's performance in terms of a degree of capital structure as low as possible. Management is supervised, it will not use the cash flows of the company for personal interest and it will not appeal to the debt because the company's profits will be reduced by the amount of interests and rates.

A third variable that explains capital structure for companies listed on the Bucharest Stock Exchange is the presence of institutional investors. As the percentage of shares held by them is higher by more overall capital structure is higher. The presence of institutional investors and debt can be complementary, so that large investors to be as sure as possible that their funds available to management are properly managed, they prefer debt because creditors monitor, also more prudent the operational activities of managers. An indebted company using funds efficiently and exploits amounts available by creditors is more profitable, earnings obtained being sufficient to cover borrowing costs and to obtain gains for shareholders.

The report Financial Debt/Equity is negatively influenced by the existence of institutional shareholders in the company, because by their own presence they provide a positive signal to investors in the market that can trust the company and can invest in its shares, bringing a substantial volume of funds necessary for the company. Under these conditions the presence of institutional investors and debt are fungible. However, institutional investors hold substantial stakes and want a high level of performance in the company, capital structure reducing earnings from the end of annual exercise.

In order to obtain more accurate and more convincing results, we consider that timeseries data collected should cover a longer period. In addition, it should be included several variables that could have an impact on the degree of capital structure. In addition, it is brought to understand that the results are influenced by the economic crisis effects, and for a better fairness it would require a comparative analysis of the results before the crisis with the present ones, to avoid distortions in the analysis.

\section{Bibliography}

- Abor, J. 2005, The Effect of Capital Structure on Profitability: Empirical Analysis of Listed Firms in Ghana, Journal of Risk Finance, 6(5): 438-45.

- Berger, P. G., Ofek, E. and Yermack, D. L., 1997, Managerial Entrenchment and Capital Structure Decisions, Journal of Finance, 52(4), 1411-1438. 
- Brailsford, T.J., Oliver, B.R., Pua, S.L.H., 2002, On the Relationship between Ownership Structure and Capital Structure, Accounting and Finance, 42, 1-26.

- Claessens S., Djankov S., Lang H.P., 2000, The Separation of Ownership and Control in East Asian Corporation, Journal of Financial Economics 58, pp.81-112.

- Fama, E., and Jensen, M., 1983, Separation of Ownership and Control, Journal of Law and Economics, 26, 301-325.

- Fosberg, R.H., 2004, Agency Problems and Debt Financing: Leadership Structure Effects, Corporate Governance, International Journal of Business in Society, 4(1), 31-38.

- Jensen, M., Meckling, W., 1976, Theory of the Firm: Managerial Behaviour, Agency Costs, and Ownership Structure, Journal of Financial Economics, 3, 305-360.

- Kim, W.S., Sorenson, E.H., 1986, Evidence on the Impact of Agency Costs of Debt on Corporate Debt Policy, Journal of financial and Quantitative Analysis, 21, 131-144

- Krishnan,V., Moyer,R., 1997, Performance, Capital Structure and Home Country: An Analysis of Asian Corporation, Global Finance Journal,8(1):130-143.

- McConnell, J., Servaes, H., 1990, Additional Evidence on Equity Ownership and Corporate Value, Journal of Financial Economics, 27, 595-612.

- Miguel, A., Pindado, J., 2001, Determinants of Capital Structure: New Evidence from Spanish Panel Data, Journal of Corporate Finance, 7, 77-99.

- Nenova T., 2000, The Value of Corporate Votes and Control Benefits: A Cross-country Analysis, Harvard University working paper.

- Pfeffer, J. and Salancick, G.R., 1978, The External Control of Organisations: a Resource dependence Perspective, Harper \& Row, New York.

- Shleifer, A., and Vishny, R., 1986, Large Shareholders and Corporate Control, Journal of Political Economy, 94, 462-488.

- Wen, Y., Rwegasira, K., Bilderbeek, J., 2002, Corporate Governance and Capital Structure Decisions of Chinese Listed Firms. Corporate Governance: An International Review, 10, 2, pp. 7583. 